\title{
МОНГОЛ-АЛТАЙН ӨНДӨР БУСИЙН БЭЛЧЭЭРИЙН ЗОНХИЛОХ ХОРЛОГЧ (Eclipophleps Serb. Tarb.) ТӨРЛИЙН ЦАРЦААТАЙ ТАХИА ХЭРЭГЛЭЖ БИОЛОГИЙН АРГААР ТЭМЦСЭН СУДАЛГААНЫ ДУН
}

\author{
Ч.Чулуунжав ${ }^{1}$, Г.Ганчимэг ${ }^{1}$, С.Гэрэлмаа ${ }^{2}$ \\ 1-Ургамал хамгааллын эрдэм шинжилгээний хүрээлэн \\ 2-Мал аж ахуйн эрдэм шинжилгээний хүрээлэн
}

\begin{abstract}
ХУРААНГУЙ
Монгол-Алтайн өндөр уулсын бүсэд тархсан Eclipophleps Serg.Tarb. төрөлд хамаарах 10 гаруй зүйл бэлчээрт хөнөөл учруулж бэлчээрийг иөлжүүлэх амьд байгалийн урьдавч хүчин зүйл болдог. Дээвэр далавчит төрлийн Богданов, Кержнер, Мөсний, Мөнххайрханы зэрэг зүйлийн ияариаатай хлорт, фосфорт, пиретройд нэгдлийн инсектииидийг 1965-2013 он хүртэл дагнан хэрэглэж тухайн газар нутгийн биоченозыг сукиессэд оруулж хорлогч шавьжийн давамгайлан тархаж ургамалд гэмтэл учруулах хүний хүчин зүйлээс болж үүсгэж байгаадаа анхаарах хугацаа аль хэдийн өнгөрсөнд биологийн шинжлэх ухааны онол, практикийн чиглэлээр авч үзэх чухал асуудал болжээ.
\end{abstract}

ТУЛХУУР ҮГ: Eclipophleps Serg.Tarb. Sturnus roseus, тахиа, амин хүчил, микроэлемент, хими, биологийн арга

\section{ОРШИЛ}

Монгол-Алтайд бэлчээрийн үет ургамлын зонхилох хорлогч Дээвэр далавчит-(Eclipophleps Serg.Tarb.)төрөлд хамаарах царцааны тархалт, зүйлийн бүрэлдэхүүний судалгааг Оросын эрдэмтэн Г.Я.Бей-Биенко (1933), Л.Л.Мищенко (1951, 1973), А.Д.Орищенко (1960) Б.Г.Шуровенков $(1960,1963)$ Монголын нэрт шавьж судлаач Л.Чогсомжав (1968-1969, 1970, $1972)$ Б.Батхуяг (1980, 1982), Ш.Батмөнх(19701980) нар туурвисан бүтээлдээ тэмдэглэсэн байдаг. Судлаачдын тэмдэглэснээр МонголАлтай болон түүний самбар уулс Говь-Алтайн нурууг дамнан оршидог 5 аймгийн 30 гаруй сумын далайн түвшингээс 1400-3800 метрт өргөгдсөн сайр чулуурхаг хөрс бүхий Agropyron cristatu L., Goezth, Stellaria petraea Bge, Arenaria
Formosa Fisch, Oxytropis trichophysa Bge, O. traga canthoides Fisch, Stipa gobica Rosher, Eurotia ceratoides L., C.A.Mey, Allium polyrrhizum Turcz, зэрэг зүйлийн үет, сонгилог ургамал зонхилсон бэлчээрт Дээвэр далавчит төрөлд хамаарах 11 зүйлээс 8 зүйл нь Монгол оронд (унаган) орогномол байдлаар амьдардаг.

Монгол-Алтайд тархсан Богданов, Мөнөххайрхан, Мөсний зэрэг зүйлтэй 1965 оноос эхлэж хлорт нэгдлийн 12 хувийн ГХЦГ-ыг 8-10кг/га тунгаар, ГХЦГ-ны 16\%-ийн изомерийг 1989 он хүртэл хэрэглэж иржээ. 1989-2013 онд Децис, Сумицидин, Кинмикс, Каратэ, хэмээх пиретройд нэгдлийн инсектицидийг 0,3-0,4л/га тунгаар жил дараалан хэрэглэж байна. 


\section{СУДАЛГААНЫ АРГА ЗУЙ}

1. Судалгааг А.С.Рубцовын шавьжийн шүҮрүүлийн зуу даллалт, нүдэн баримжаа, цэгийн аргыг хэрэглэж бэлчээрийн ам метр дэхь царцааны тархалтын коэффициентийг тодорхойлов.

\section{СУДАЛГААНЫ УР ДУН}

Ховд, Баян-Өлгий, Увс, Говь-Алтайн бэлчээрийн талбайд Дээвэр далавчит-(Eclipophleps Serg.Tarb.) төрлөөс Богданов, Мөнххайрхан, Мөсний, Кержнер зэрэг зүйлийн царцааны тархалт, олширолт, хөнөөлийн ихсэлт нь хуурайшилтын индекс 0,05 -аас ялимгүй буурсан жилд бий болж байгааг Ховд аймгийн Мөст сумын цаг уурын харуулын 20 жилийн материал дээр боловсруулалт хийж тодорхойлов. Хуурайшилтын индекс тэгш тоотой он жилд 0,05-аас ялимгүй буурхад бэлчээрийн ам метрт 125-600 гаруй бодгалийн нягтралттай тархаж бэлчээрийн ургацыг 1,2-2,5ц/га-гаaр бууруулдаг(7).

Харин сондгой тоотой он жилд хуурайшилтын индекс 0,05-аaс ихсэж буух тунадасны хэмжээ ихэсдэг. Ийм он жилд царцааны гаралт, тоо хэмжээ бараг мэдэгдэхгүй өнөтэй жил болдог. Ийм тоон үзүҮлэлттэй жилд ч царцаагаар хооллодог Ягаан тодол хэмээх полигам шувуу тэгш тоотой он жилд үй олноороо (нэг сүрэгт) 500-гаaс доошгүй тоогоор сүрэглэн ирж царцаагаар хооллодог.
2. Царцааны уураг, амин хүчил, микроэлементийг MNS4961-66-1995, AAC,

3. Ягаан тодол, тахиаг хэрэглэн царцаатай тэмцэх ажлыг 2 хувилбараар хээрийн ба оторт гаргаж судлав.

Нэг Ягаан тодол өдөрт 200 граммаас доошгүй царцаагаар хооллодог ба тодлын 10000 сүрэг нэг сарын дотор 108 тонн бэлчээрт тархсан царцаагаар хооллодог болохыг тогтоожээ (1). Тодол Үүрлэсэн нутаг бэлчээрт царцааны тархалт, олширолт гурван жилийн туршид бий болдоггүйг туршилтаар тогтоолоо. Дээвэр далавчит төрлийн царцаатай биологийн аргаар тэмцэх судалгаанд тодлоос гадна өндөглөлт нь зогссон махны чанар доройтсон тэжээвэр тахиаг зуны гурван сард хээрийн оторт гаргаж царцаагаар хооллуулж махны чанарыг сайжруулах, биеийн жинг нэмэгдүүлсэн.

Дуут суманд бэлчээрийн ам метрт 26,7-27 бодгаль тархсан нэг га талбайг хашиж 50 тахиаг оруулж туршихад 40 минутын дотор царцааг 98,1 хувиар идэж устгасныг тогтоосон болно.

Дээвэр далавчит төрлийн царцаатай тахиаг оторт гаргаж биологийн аргаар Дуут, Буянт сумын нутагт тэмцсэн ажлын үр дүнг 1, 2 дугаар хүснэгтээр ҮзҮүлэв. 


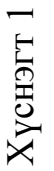



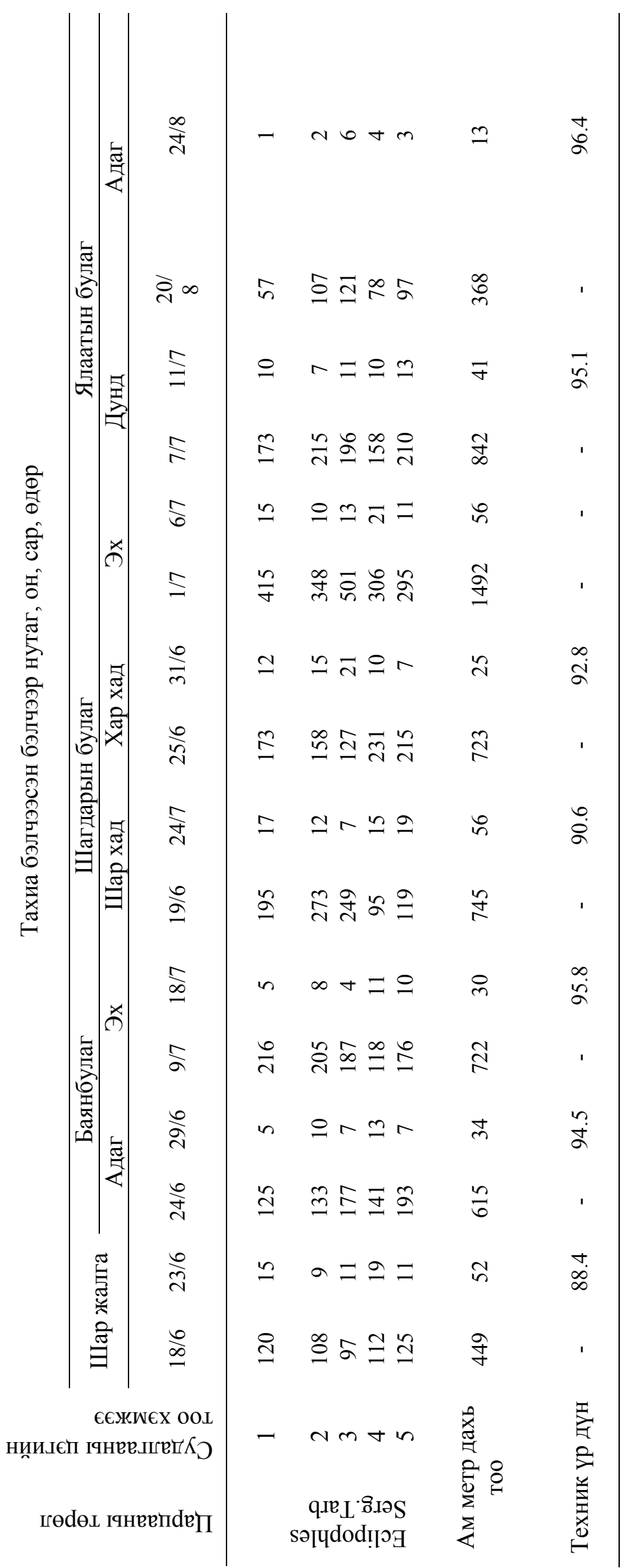


Хүснэгт 2

Ховд аймгийн Буянт сумын бэлчээр нутагт тархсан царцаатай тахиа оторлож тэмцсэн судалгааны дүн 2008 он

\begin{tabular}{clccc}
\hline д/д & Газар нутгийн нэр & $\begin{array}{r}\text { Тахиа оторлохын өмнөх ба эцэс дэх } \\
\text { ам метр дэх царцааны тоо }\end{array}$ & Техник үр дүн (хувь) \\
\hline 1 & Ар цагаан бургас & 85 & 6 & 90.2 \\
2 & Өвөр цагаан бургас & 92 & 9 & 94.6 \\
3 & Марцатан эх & 75 & 4 & 91.1 \\
4 & Ар хөтөл ус & 68 & 6 & 90.4 \\
5 & Уурхай & 53 & 7 & 92.4 \\
6 & Сорхид & 78 & 3 & 96.2 \\
\hline & Дундаж & 64.5 & 5 & $=$ \\
\hline
\end{tabular}

Дээрх хоёр суманд ам метрт тархсан царцааны тоо, талбайн хэмжээнээс хамаарч тухайн газруудад 2-7 хоногийн турш 400 гаруй тахиаг оторт гаргаж өдөр бүр 11-12 цаг бэлчээрлүүлэхэд тэмцэх ажлын техникийн үр дүн дундажаар 92,896,4 хувь болохыг судлан тогтоолоо. Өглөөний 7-8 цагт нэг тахиа $1200,9-10$ цагт $360,10-11$ цагт 180 бодгаль царцааг идэж устгадаг. Өдөрт 11 цаг бэлчээрлүүлэхэд 3500-5290 бодгаль царцааг идэж устгадаг.
Хэрэв 500 тахиаг оторлоход өдөрт 1750,0 мянган бодгаль царцаа 70-80 хоногт доод тал нь 12250.0 мянган царцаагаар хооллож үйлдвэрлэлийн тэжээлийг хэрэглэхгүй хэмнэхийн байгалийн ямарч үнэгүй байгаа уургийн нөөцийг ашиглаж өндөг, мах авах боломтой. Царцаатай тахиа хэрэглэж тэмцэж байгаа ажиллагаа нь байгаль орчинд ямарч сөрөг дагаваргүй харин сангасаар нь бэлчээрийн хөрсийг органик бордоогоор бордох ажиллагаа үр ашигтай болно.

Хүснэгт 3

Хээрийн бүсэд зонхилон тархсан царцааны хатаасан эд эрхтний химийн бүтэц, тэжээллэг бүтэц

\begin{tabular}{|c|c|c|c|c|c|}
\hline \multirow[b]{2}{*}{ № } & \multirow[b]{2}{*}{$\begin{array}{c}\text { Шүвтэн хүчлийн } \\
\text { нэр }\end{array}$} & \multirow[b]{2}{*}{ Уургын эх сурвалж } & \multicolumn{2}{|c|}{$\begin{array}{c}\text { Сибир царцаа зонхилсон } \\
\text { тэжээл }\end{array}$} & \multirow{2}{*}{$\begin{array}{c}\text { Мах, ясны гурил } \\
\text { Гурилд байгаа } \\
\text { шүвтэн хүчил } \\
\text { г/кг М.Ф.Томмэ }\end{array}$} \\
\hline & & & $\begin{array}{c}\text { Уураг эзлэх } \\
\text { хувь } \\
49,15 / 100\end{array}$ & $\begin{array}{l}\text { Шинжилгээний } \\
\text { дүн 491,5 г/кг }\end{array}$ & \\
\hline 1 & Цистин /Т/ & Төлөөлөгдөх & 3,72 & 18,3 & 7,3 \\
\hline 2 & Лизин /Y, т/ & Үл төлөөлөгдөх & 5,52 & 27,1 & 29,1 \\
\hline 3 & Гистидин & Үл төлөөлөгдөх & 5,86 & 28,8 & 12,5 \\
\hline 4 & Арганин & Үл төлөөлөгдөх & 3,79 & 18,6 & 33,1 \\
\hline 5 & Аспарагины хүчил & Төлөөлөгдөх & 6,99 & 34,3 & 54,7 \\
\hline 6 & Серин & Төлөөлөгдөх & 5,85 & 28,7 & 10,5 \\
\hline 7 & Глутамины хүчил & Төлөөлөгдөх & 8,69 & 42,7 & 54,7 \\
\hline 8 & Глицин & Төлөөлөгдөх & 8,27 & 40,6 & 43,2 \\
\hline 9 & Треонин & Үл төлөөлөгдөх & 8,69 & 42,7 & 18,1 \\
\hline 10 & Аланин & Төлөөлөгдөх & 4,91 & 24,1 & 21,1 \\
\hline 11 & Пролин & Үл төлөөлөгдөх & 5,68 & 27,9 & 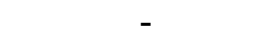 \\
\hline 12 & Триозин & Үл төлөөлөгдөх & 2,28 & 11,2 & 10,0 \\
\hline 13 & Метионин & Үл төлөөлөгдөх & 5,49 & 26,7 & 11,0 \\
\hline 14 & Валин & Үл төлөөлөгдөх & 3,93 & 19,3 & 23,1 \\
\hline 15 & Фенилаланин & Үл төлөөлөгдөх & 4,73 & 23,2 & 17,1 \\
\hline 16 & Лейцин & Үл төлөөлөгдөх & 9,84 & 48,4 & 45,6 \\
\hline
\end{tabular}

Төлөөлөгдөх ба үл төлөөлөгдөх шүвтэн хүчлийн агууламж, нэр төрөл царцааны эд эрхтэнд бүрэн агуулагдаж байна. М.Ф. Томмэгийн судалгааны яс махны найрлагатай харьцуулан үзэхэд төдийлөн дутахааргүй ба төлөөлөгдөх амин хүчил Цистин, Сериний агууламжаар нэг дахин их байх ба Аспарагины хүчил, Глицин, Глутамины хүчил, Аланины хэмжээгээр тун ойролцоо, үл төлөөлөгдөх 10 аминхүчлийн агууламжаар ихэнхидээ давуу байна.

Царцааны нунтаглан хатаасан түүхий эд 4,41 хувийн чийгтэй, 81,6 хувийн хуурай бодистой, 
6,47 хувийн үнстэй, 7,44 хувийн тослогтой болно. Мөн царцааны түүхий эдийн 60 гаруй хувийг уураг эзэлдэг. Энэхүу уургийн бодис нь фермент, пептид, уурагт нэгдлүүд эзэлдэг. Уураг нь төлөөлөгдөх ба үл төлөөлөгдөх 16 амин хүчил бүгд агуулагдана.
Зургаан нэрийн үл төлөөлөгдөх шүвтэн хүчлийн хэмжээ 82,7моль байгаa нь орлогдох амин хүчлийн хэмжээнээс хоёр дахин их болохыг илрүүлсэн байдаг.

Дээвэр далавчит (Eclipophleps Serg.Tarb.) төрлийн царцааны

Хүснэгт 4 эд эрхтэнд агуулагдах бодисын хэмжээ (\%), 2010 он

\begin{tabular}{|c|c|c|c|c|c|c|c|c|c|c|c|c|c|c|}
\hline 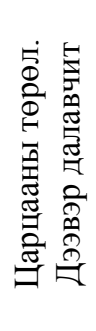 & 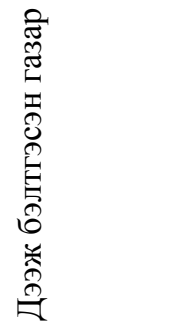 & 惫 & 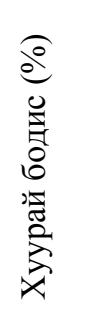 & $\begin{array}{l}\widehat{o} \\
\stackrel{0}{2} \\
\stackrel{2}{2}\end{array}$ & 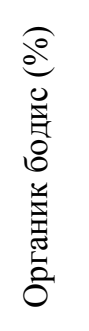 & 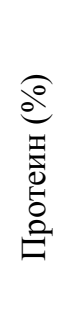 & 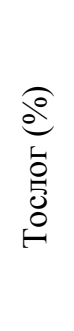 & $\begin{array}{l}0 \\
0 \\
0 \\
0 \\
0 \\
0 \\
0\end{array}$ & 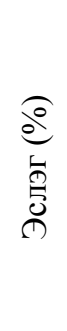 & 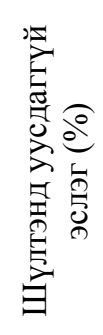 & 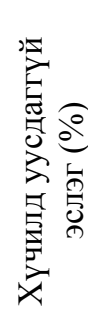 & 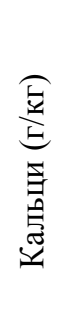 & 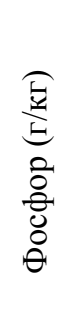 & 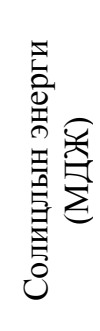 \\
\hline \multirow{2}{*}{ 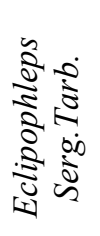 } & \multirow{2}{*}{ 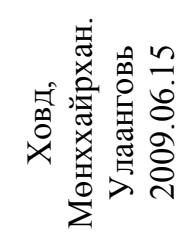 } & 8,2 & 91,8 & 5.1 & 86,7 & $\begin{array}{l}49 \\
2\end{array}$ & 4,4 & $\begin{array}{l}33, \\
1\end{array}$ & $\begin{array}{l}16, \\
9\end{array}$ & 33,7 & $\begin{array}{l}33, \\
8\end{array}$ & $\begin{array}{l}4, \\
6\end{array}$ & 7,6 & $\begin{array}{l}14, \\
3\end{array}$ \\
\hline & & 0 & 100 & 5,6 & 94,4 & $\begin{array}{l}53, \\
6\end{array}$ & 4,8 & $\begin{array}{l}36, \\
1\end{array}$ & $\begin{array}{l}18 \\
4\end{array}$ & 35,6 & $\begin{array}{l}36, \\
8\end{array}$ & $\begin{array}{l}5, \\
1\end{array}$ & 8,3 & $\begin{array}{l}15, \\
3\end{array}$ \\
\hline
\end{tabular}

Царцааны эд эрхтний химийн бүтцийг MNS 4961-66-1995 дагуу шинжилж тэжээллэг чанарыг тодорхойлоход уургын агууламж (чин хуурайд $53,6 \%$ ) өндөр сайн чанарын тэжээл болох нь тодорхойлогдов. Чийглэг- $8,3 \%$, Тослог $-4,2 \%$,
Уураг -49,15\% , АХБ- 31,35\%, эслэг- 7\%, Царцааны шимт чанар 1 кг царцаа 1,14 тэжээлийн нэгж, шингэх протеин 395 г/кг, Солилцлын энерги - 3405 ккал/кг болно.

Дээвэр далавчит -(Eclipophleps Serg.Tarb.) төрлийн царцааны

Хүснэгт 5 эд эрхтэнд агуулагдах микроэлемент (мг/кг), 2012 он

\begin{tabular}{|c|c|c|c|c|c|c|c|c|c|c|c|c|}
\hline \multirow[t]{2}{*}{ Д/д } & \multicolumn{2}{|c|}{ Хром (Cr) } & \multicolumn{2}{|c|}{$\begin{array}{l}\text { Кобальт } \\
(\mathrm{Co})\end{array}$} & \multicolumn{2}{|c|}{ Төмөр (Fe) } & \multicolumn{2}{|c|}{ Цайр (Zn) } & \multicolumn{2}{|c|}{ Зэс $(\mathrm{Cu})$} & \multicolumn{2}{|c|}{$\begin{array}{c}\text { Мангани } \\
(\mathrm{Mn})\end{array}$} \\
\hline & $\overline{\Delta \wedge}$ & $\mathrm{M \Gamma} / \mathrm{KГ}$ & AAC & & $\Delta \Delta C$ & 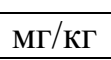 & $\mathrm{C}$ & & $\mathrm{AC}$ & & $\mathrm{AAC}$ & \\
\hline 1 & & & & & & & & & & & & \\
\hline 2 & & & & & & & & & & & & \\
\hline нд & 0,015 & 0,108 & 0,11 & 1,251 & 0,091 & 14,28 & 0,533 & 8,4 & 0,135 & 6,21 & 0,038 & 2,455 \\
\hline
\end{tabular}

Хайсан торны 20 тахианы хоногийн тэжээлийн 0.3 хувийг царцааны нэмэгдэлтэй тэжээл хэрэглэхэд өндөглөлтийн эрчим хяналтын бүлгийнхээс харьцангуй илүү, өндөглөлт жигд явагдаж байгааг МААЭШхүрээлэнгийн эрдэм шинжилгээний ажилтан С.Гэрэлтэй (2010) хамтын судалгаагаар тодорхойлов.

Туршлагын шувууны өндөгний жин (г)

\begin{tabular}{ccccccc}
\hline \multirow{2}{*}{ Бүлэг } & Тахианы & \multicolumn{5}{c}{ Бүлэг } \\
\cline { 3 - 7 } & тоо & I & II & III & IV & V \\
\hline Хяналт & 20 & 58.04 & 58.1 & 58.2 & 59.7 & 59.4 \\
Царцаа & 20 & 59.2 & 59.4 & 60.0 & 60.6 & 60.5 \\
\hline
\end{tabular}


Өндгөнд хийсэн шинжилгээний дүн (г/мг)

Хүснэгт 7

\begin{tabular}{cccc}
\hline Д/д & Шинжилсэн үзүүлэлтийн нэр & Хяналт & Царцаа \\
\hline 1 & Цагаан уураг & 34.7 & 35.9 \\
2 & Шар уураг & 15.5 & 15.9 \\
3 & Уураг & 12.03 & 12.35 \\
4 & Витамин А,мг & 0.005 & 0.005 \\
\hline
\end{tabular}

Туршилгын өндөглөг тахианы өндөглөлт

Хүснэгт 8

\begin{tabular}{|c|c|c|c|c|c|c|c|c|c|c|c|}
\hline \multirow{3}{*}{ Бүлэг } & \multirow{3}{*}{$\mathrm{N}$} & \multicolumn{10}{|c|}{ Өндөглөлт } \\
\hline & & \multicolumn{2}{|c|}{ I.7 хоног } & \multicolumn{2}{|c|}{ II.7 хоног } & \multicolumn{2}{|c|}{ III.7 хоног } & \multicolumn{2}{|c|}{ IV.7 хоног } & \multicolumn{2}{|c|}{ V.7 хоног } \\
\hline & & Ш & $\%$ & Ш & $\%$ & Ш & $\%$ & Ш & $\%$ & Ш & $\%$ \\
\hline Хяналт & 20 & 120 & 85.7 & 121 & 86.4 & 123 & 87.8 & 123 & 97.8 & 126 & 90.0 \\
\hline Царцаа & 20 & 128 & 91.8 & 128 & 91.8 & 128 & 91.8 & 131 & 93.5 & 132 & 94.1 \\
\hline
\end{tabular}

Өндөглөлт нь дууссан хайсан торны тахиаг зургаан сарын хоёрдгаар арав хоногоос хээрийн оторт 60 хоног гаргахын өмнө дундажаар нэг тахианы амьдын жин 1010г байсан бол отроос буухад 2130г буюу 1120 граммаар нэмэгдсэн байлаа. Оторт гарсан тахианд ямарч нэмэгдэл тэжээл хэрэглэхгүй бөгөөд суурин маллагааны үеийн тэжээлийг бүрэн хэмнэх боломжтой. Царцаагаар хооллосон тахиа амархан цангадаг

\section{ШУУН ХЭЛЭЛЦЭХУЙ}

Дэлхийн улс орон хүн, мал амьтнаа экологийн цэвэр хүнс тэжээлээр хангах тэргүүн зорилтыг дэвшүүлсээр байна. Гэтэл манай улс бэлчээрийг хорлогч шавьжаас хамгаалах чиглэлээр ургамал хамгаалах химийн аргыг давамгайлан хэрэглэх арга туршлагаa багасгах асуудал зүй ёсоор шаардадаж байна. Ургамал хамгаалах биологийн аргад Ягаан тодол шувууг хэрэглэж байгаa

\section{ДУГНЭЛТ}

1. Дээвэр далавчит (Eclipophleps Serg.Tarb.) төрөлд Eclipophleps bogdanovi, E. tarbinskii Oristsh, E. similis L., Mishch, E.kerzhnerri L., Mishch, E. glacialis B-Bienko, E.lucida L., Mistch, E.confinis L., Mistsh, E.confinis confinis L., Mishch, E.confinis Levis L., Mistsh. зэрэг зүйл Монгол-Алтай болон түүний салбар уулс хоорондын хөндийн бэлчээрт тархсан ба Богданов, Кержнер, Мөнххайрхан буюу Тарбинский, Мөсний хэмээх зүйлүүд зонхилон тархаж бэлчээрийн ургацыг 1,2-2,5 ц/га-гаар бууруулдаг болохыг тогтоов. учраас хариулгын замд услагааны савыг цэвэр усаар дүүргэж байрлуулах шаардлагатай. Нэг тахиа өдөрт 130-210 грамм гаруй сангас ялгаруулдаг. Иймээс тахиаг царцаатай тэмцэх биологийн аргад хэрэглэхийн зэрэгцээ бэлчээрийн ургамал, хөрсийг органик бордоо буюу сангасаар ямарч давхар зардал гаргахгүйгээр бордож бэлчээрийн ургамлын ургалтыг сэргээн өгдөг давуу талтай болно.

дэвшилтэт технологийг Казахстан улсад 1910 оноос эхлэн туршиж улмаар үр тарианы талбайгаа буюу ургацыг нүүдлийн царцаанаас хамгаалахад Ягаан тодолд үүр засаж биологийн аргаар хамгаалдаг бэлэн туршлага байгаa болно. Тахиа, галуу, нугасыг ч царцаатай тэмцэх биологийн аргад хэрэглэх бүрэн боломжтой.

2. Бэлчээрт хөнөөл учруулдаг нь хуурайшилтын индексээс хамаардаг. Индекс 0,05-аaс буурахад царцааны олширолт болж байхад энэхүҮ индекс ихэсэхэд царцааны тархалт ҮҮсдэггүй болно. Үүнтэй уялдаж тэгш тоогоор төгссөн он жилд царцааны тоо бэлчээрт хөнөөл учруулах тоо хэмжээнд хүрч байхад сондгой тоогоор төгссөн он жилд тэдгээрийн олширолт болдоггүй болохыг илрүүлэв.

3. Монгол-Алтайд тархсан царцаатай ургамал хамгаалах биологийн аргаaр нүүдлийн шувуу-(Sturnus roseus L.,), болон тэжээвэр тахиаг зуны улиралд хээрийн оторт гаргаж 
тэмцэхэд техникийн үр дүн 92,8-96,4 хувьтайг тогтоолоо

4. Ягаан тодол өдөрт 190-200г царцаагаар хооллодог ба тахиа 280-350г буюу 3500-5290 бодгаль Eclipophleps Serg.Tarb. төрлийн царцааг идэж хөнөөдөг болохыг илрүүлэв.

5. Монгол орны бэлчээрт тархсан царцааны эд эрхтний дотор агуулагдаж байгаа төлөөлөгдөх үл төлөөлөгдөх амин хүчлийг яс махны гурилтай харьцуулж тодорхойлоход царцаа, яс махны гурилд ойролцоо болохыг тодорхойлов.

6. Дээвэр далавчит-(Eclipophleps Serg.Tarb.) царцааны хатаасан эд эрхтний агууламжин дах бодисыг хувиар илэрхийлж тэжээлэг чанарыг тодорхойлоход чин хуурайд уураг

\section{НОМ ЗУЙ}

1. Ковшар 6 А.Ф.1988. Мир птиц казахстана. Алма-Ата, “Мектел” с.210

2. Мищенко Л.Л. 1973. Саранчовые рода Eclipophleps Serg.Tarb.Энтомологическое обозрение L11,1

3. Наумович О.Н, Столёров М.В, и др. 2000 Рекомендацин по мониторингу в борьбе с вредными саранчовыми. М, "Колос"

4. Степанян Л.С, 1978. Состав и распределение птиц фауны СССР. Наука.

5. Степанов Е.А, 1987. Розовие скворцы в борьбе саранчы. Наука с 41.

6. Цыпленков Е.П, 1979. Методические указания по борьбе вредными саранчовыми. М, "Колос"

7. Чулуунжав Ч. 2003, “Бэлчээрийн хорлогч царцаатай тэмцэх загварчилсан арга” №1 Улаанбаатар хот

\section{CONCLUSION}

1. The genus Eclipophleps Serg.Tarb includes Eclipophleps bogdanovi, E.tarbinskii Oristsh, E.similis L, Mishch, E.kerzhnerri L, Mishch, E.glacialis B-Bienko, E.lucida L., Mistsh, E.confinis L, E.confinis confinis L., Mishch, E.confinis Levis L., Mistsh etc. These species are the most species, spreads in Mongolian Altai Mountain and their valley pasture located between the mountain branches. We determined that this species decreased the yield of pasture with $1.2-2.5 \mathrm{c} /$ hectare.

2. Caused from the dryness index in Mongolian Altai the spread and the multiplication of
$53.6 \%$ бол чийг 8,3 , тослог 4,2 уураг 49,15 АХБ 31,35, ислэг 7 хувиар агуулагдах бөгөөд нэг килограмм хатаасан царцааны шимт чанар 1,14 тэжээлийн нэгж, шингэх протеин 395г/кг, солилцлын энерги 3405 ккал/кг болохыг тодорхойлов.

7. Мөнххайрханы царцаа зонхилсон хатаасан царцааны гурилд хром, кобальт, төмөр, цайр, зэс, мангани зэрэг бичил элемент болон В төрлийн витамин агуулагдаж байгааг судалж гаргав.

8. Хайсан торны тахианы тэжээлд 0,3\%-иар царцааны гурил нэмж хяналтын тахиатай харьцуулан 20 хоног тэжээхэд өндөглөлт хэвийн буюу өдөр бүр өндөглөж, өндөгний жин 1,1 хувиар нэмэгдэж байгааг илрүүллээ.

8. Чулуунжав Ч. 2007, “Бэлчээрийн хорлогч царцаатай тахиа хэрэглэн биологийн аргаар тэмцэх загварчилсан арга” №2 Улаанбаатар хот

9. Чулуунжав Ч., Батнаран Х. 2008 "Eclipophleps Serg.Tarb. төрлийн царцаатай тэмцэхэд Ягаан тодлыг хэрэглэх асуудалд" Экологи ургамал хамгаалал хуу.45. Улаанбаатар хот

10. Чулуунжав Ч, Ганчимэг Г, Ичинхорлоо Б. 2011 Дөрөвжин далавчит- (Eclipophleps Serg.Tarb.)төрлийн царцаатай биологийн аргаар тэмцэхэд тахиа хэрэглэх судалгаанд Монгол фермер дээд сургуулийн Эрдэм шинжилгээний бичиг. №11

Eclipophleps Serg.Tarb is very harm for the pasture. When the dryness index is lower than 0.05 the number of grasshoppers increases and on high dryness index there was no change for the number of grasshopper. We also observed the growth of grasshopper increases in even year and very harm for pasture and no number change in odd year.

3. Fight with the grasshoppers in Mongolian Altai with biological method, pasturing the Sturnus roseus L., and hen for fattening. The technical result was $92.8-96.4 \%$. 
4. We determined the rose colored starling feed with about 190-200 gram, hen about 280-300 grams daily that means it is approximately 3500 5290 Eclipophleps Serg.Tarb.

5. Compare the essential and non essential amino acids in the dried grasshopper's tissues from Mongolian pastureland with the bone-meat flour.

6. Evaluated the matter in the dried grasshoppers and determined the nutritional quality with percents, protein in dried mass was $53.6 \%$, humidity $8.3 \%$, fat $4.2 \%$, protein $49.15 \%$, nitrogen extract matter-31.35\%, dietary fiber 7 $\%$.
The nutritional quality in $1 \mathrm{~kg}$ dried grasshoppers was 1.14 fodder units, digestible protein 395 $\mathrm{g} / \mathrm{kg}$, and energy $3405 \mathrm{kcal}$.

7. The dried grasshopper flour which contains mostly E.tarbinskii includes microelements such as chrome, cobalt, ferium, zinc, mangane, copper etc, and also B vitamins.

8. We feed the hens adding 0.3 percents of grasshoppers flour within 20 days, compared with the control hen, the laying of eggs were normal it means the hens lays daily and the weight of the eggs increased with1.1 percents. 